\title{
Feasibility and Occupants' Perception of Double Skin Façade for Historical Buildings in Kuwait
}

\author{
A. Al Anzi ${ }^{a *}$ and L. Al-Dihani ${ }^{b}$ and A. Al-Ragam ${ }^{a}$ \\ ${ }^{a}$ College of Architecture, Kuwait University, Kuwait \\ ${ }^{b}$ Kuwait Municipality, Kuwait City, Kuwait
}

\begin{abstract}
The paper focuses on diagnosing the Double Skin Facade (DSF) of the main Kuwait Municipality building complex based on occupants' perception of different historical and environmental preferences. The case study building complex has a remarkable façade that represents the modern architectural and democratic movement of Kuwait. Unfortunately, due to improper maintenance and operation, the significance and benefits of the DSF in particular have not been utilized in this complex. The objective of this paper is to diagnose the DSF benefits of this building envelope and discuss the feasibility of renovation to improve its sustainable use and operation. Such sustainability includes daylighting, thermal comfort, indoor air quality (IAQ), and acoustic performances. To reach this objective, the study will be carried out using quantitative and qualitative research methods, such as site visits, interviews, questionnaire and literature review. It is found that responses of occupants are positive on the advantages and rehabilitations of the DSF of the complex. And based on the findings of this study, it is also believed by the authors that the preservation of its DSF is a more sustainable choice in this green architectural era. This is so due to its great occupants' performance expectations and energy savings opportunities.
\end{abstract}

Keywords: Double Skin Facade, Facade Rehabilitation, Multiple-Skin Façade, Sustainable façade, thermal comfort

\section{Introduction}

The remarkable double skin Facade of the Municipality building complex in Kuwait City suffer from improper being unmaintained since the 1990s. This Facade has a great significance in Kuwait history, as it was a symbol of development and modernity, since it represents the beginning of Kuwait independence and democracy. The Municipality building complex consists of three semi identical buildings as shown in Fig. 1 and Fig.4 [1]. The first national assembly building has a great significance in the complex due to its political symbolism. The significance of the complex façades is not only limited to its symbolism but also to its curtain wall environmental solution. In fact, one of the main intentions of DSF is to improve space daylighting while accomplish energy savings. In addition, DSF improves human comfort and acoustics. The double skin façade is recommended for two reasons: first, glass is an industry driven architecture. Second,
DSF is a good solution to reduce the environmental consequences of curtain walls as discussed thoroughly in the literature [19].

The first part of the paper presents the literature review. This literature review presents and discusses the definition, conceptual idea, history, and classification of the DSF based on the important criteria. Then, a comparative analysis for some of their classifications is carried out. Finally some case studies for DSF in similar weather conditions of Kuwait are presented and discussed.

The second part of the paper examines the qualitative and quantitative methodologies used in this study. Finally, analysis and discussion of results for the present situation and the possible success for rehabilitation of the Kuwait Municipal Building complex is demonstrated.

${ }^{*}$ Corresponding author. Tel.: +96524985128

Fax: +96524846308; E-mail: alanzi2001@yahoo.com

(C) 2017 International Association for Sharing Knowledge and Sustainability

DOI: 10.5383/ijtee.14.01.009 


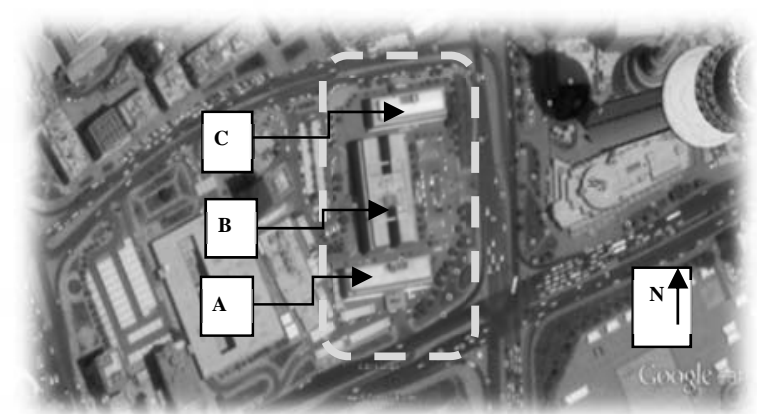

Fig. 1. A Google aerial view shows the setting of the three buildings in the municipal complex [23].

\section{Literature Review}

The DSF can be defined as single or double glazed facades that are located on two layers separated by a space. Each of these two facades are commonly called a skin. The width of the separating space can range from $20 \mathrm{~cm}$ up to 2 meters. The main layer of glass, usually optically treated, serves as a part of a conventional structural wall or a curtain wall. Sun-shading devices are often located between the two skins to further control solar radiation. Therefore, the main purpose of DSF is to maximize daylight and to improve energy consumption along with ventilation purposes. [18], [19]. Fig. 2 presents visually the concept of DSF.

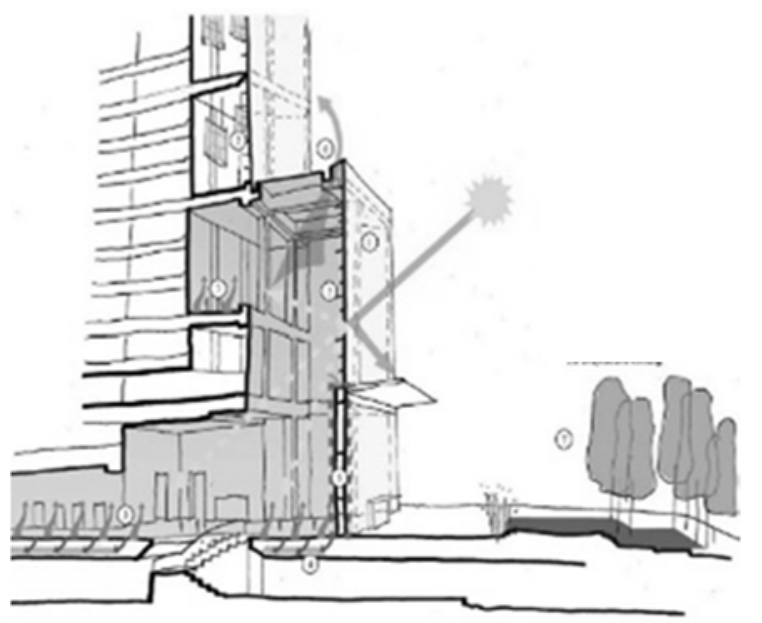

Fig. 2. Conceptual Idea for the DSF [24].

Historically speaking, The DSF origins are attached to the European green house and French "orangerie", established in the early nineteenth century, and then developed into massive horticultural conservation in England [14], [19].

Some research studies suggested that the DSF has many classifications, the criteria for those classifications is based on the type of ventilation, partitioning of the air cavity, and ventilation mode [18].

The type of ventilation refers to the driving force used to ventilate the air cavity between the two glazed facades. It consists of three kinds the natural ventilation or the passive facade, the mechanical ventilation, fan supported or the active façade. There is also what is so called the hybrid or the interactive ventilation façade [18]. Partitioning refers to the physical division of the air cavity. It is divided into four type: the box window façade, the corridor type, the shaft-box façade and the multi-storey facade [19], [3], [18]; Fig. 3 show the different types of DSF.

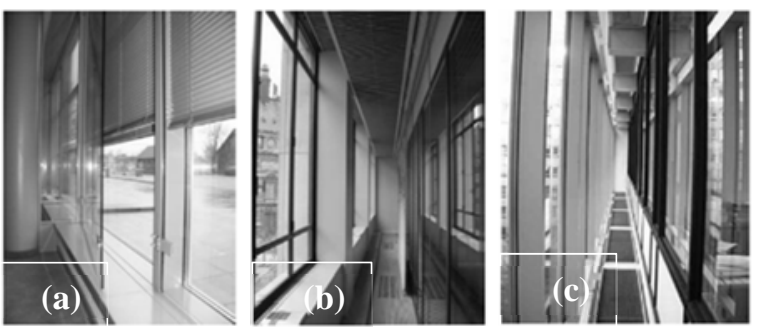

Fig. 3. Different cavity corridor type. (a) Box Window, (b) Corridor Facade, (c) Multi storey Façade [25].

Ventilation mode refers to the origin and destination of the inlets. There are five ways of ventilation mode: the outdoor air curtain, the indoor air curtain, the air supply, the air exhaust, and the air buffer [18].

In order to succeed in the enhancement of occupant's thermal comfort and achieving energy conservation, it is vital to understand the thermal physics of DSF's. Many parameters determine the thermal behavior of DSF. Such parameters include and not limited to: geometry, glass type, shading devices, and the size and position of the interior and exterior openings. These factors have big impacts on HVAC use and operation. Consequently, these aspects determine occupants use and comfort [16].

The advantages shows that the DSF lowers the construction cost if we compare it with high-tech spectrally selective glass panes. In addition, DSF works as an acoustic and thermal insulation. DSF is also advantageous for night time ventilation, by natural cross ventilation. As a consequence, energy saving is achieved due to the thermal, optical and ventilation design advancement of the DSF. Extra advantage also resulted in the use of the cavity as a fire escape especially with the corridor type [19], [18].

The disadvantages of the DSF's are known in practice. The most obvious ones are: extra cost, fire spread, increased maintenance, and reduced rentable area along with acoustics concerns by occupants. However, the main concern in this study is the problem with the thermal environment. In particular, improper design of DSF might cause overheating and increased air flow speed in the cavity. Indeed, this is obvious in cavities of less than $200 \mathrm{~mm}$. In addition, some researchers noted concerns in space day lighting qualities due to multiple glazing [19], [18].

Different case studies from the Middle East are presented to show the potential success of DSF in hot and arid climates. DSF's are not common in Kuwait. In fact, the case study in consideration is the only existing building with DSF façade in Kuwait. The only known study regarding DSF in Kuwait is done by Aasem [1].

Aasem performed a theoretical analysis study using building energy simulation. His study was on a typical office building with nine scenarios. His results concluded the feasibility of an additional glass layer to the laminated skin in reducing the cooling load and annul energy consumption [1].

In another study, a comparison between five scenarios of facades was done by Aksamija [2], by using a simulation study in Abu Dhabi, UAE. In this study, the results show that DSF's perform better than conventional façades in winter, but remain the same in summer. The DSF with smaller air cavity and low-e or reflective coating performed much better in reducing energy consumption compared to the wider one. The five scenarios did not show a comparison between the mechanical and hybrid ventilated mode for such a climate; however, the author of those scenarios recommended the hybrid ventilated mode for such swinging climate as the mechanical will be effective during the daytime and the natural ventilated mode during the night-time. The author of those scenarios also recommend the shading 
device in addition to the overhang for such climate for their importance in blocking the direct sunlight to the interior, especially the taller building with the shading device. The low-e or reflective glazing are recommend too for such climate for their importance in decreasing the cooling load during the summer months.

Another simulation study was done by Aksamija for another multi- storey building in Abu Dhabi, UAE with a hybrid mode of ventilation [3]. The results recommend the use of DSF to improve performance compared to the conventional double or triple glazed facade. In fact, the reduction of the cavity size and using low-e or high performance glazing accelerate air pressure and improve air flow. It was also observed that very deep overhang projections will not make a serious thermal improvement [3].

In another study, an actual field measurement and simulation study done by Hashemi [15] in Tehran, Iran to evaluate the thermal behaviour in an existing mid-rise office building. In the actual field he monitored the Facade for two weeks in summer and another two weeks in winter. They discovered that DSF save heating energy in winter and reduce cooling load in summer with the use of shading devices in the cavity and allow night ventilation.

In another study, a building energy audit is performed in a midrise office building in Cairo, done by Hamza [13], [14] and used it as a base case. A simulation study is then performed and experiment with the possible success of DSF as a retrofit. The study concluded the feasibility of DSF façade with $1 \mathrm{~m}$ cavity and low shading coefficient.

\section{Methodology}

In order to examine the complex current situation and their needs to be rehabilitated, the study is based on three main elements: interviews, data collection, and a questionnaire.

The interviews were taken from selective participants who have witnessed some or most of the developments in the complex. In particular, participants who are in charge of civil mechanical and electrical maintenance that witnessed some or most of the buildings development through the complex's life.

The data collection was gathered from as built drawings as well as old and current photos. The as built drawings were survived by the maintenance department, since the original drawings (plans, sections elevations) are missing since the Gulf War in 1991. Missed details from the building drawings with related to the development and the current situation of the DSF were added along with a basic section for one of the complex. The first and second elements were the main key for the third main element which is the questionnaire. The interviews and the data collection served in generating and designing the kind of questions listed in Table 1 . The aim of the questionnaire was to measure the participants' awareness in the importance of maintaining, keeping and rehabilitating the complex of Kuwait Municipality for their importance in Kuwait history. In addition, it aims to check the façades need for renovation in the current situation in terms of healthy ventilation, thermal comfort, natural lighting, aesthetic and sound pollution. The questionnaire will assist to test the argument and hypothesis by measuring the majority of the complex regular occupant's points of view and experiences.

The questionnaire is then distributed to occupants of the municipal complex to measure their perception and satisfaction of their spaces in relation to the DSF. The questions of Table 1 are organized based on seven different design and environmental categories. The given seven different categories are as follow: general, indoor space location, historical preference, dayligting, thermal comfort, indoor air quality (IAQ) and acoustics. The questionnaire is given to 321 participant occupants. The choice of the hierarchy of employees was randomly selected, ranging from vice president to normal technicians including males and females. Some had offices facing the double skin façade, and some others had window openings. The type of jobs of those participants was a mixture of lawyers, engineers, accountants, draftsmen, and technicians.

In order to measure the complex needs for rehabilitating, a manual questionnaire consisted of 21 elective questions. The authors were able to create the questionnaire after visiting the complex and taking photos of its current situation and after meeting the specialist employees who were in charge of the construction and maintenance, due to their continuous involvement with the complex development and operation.

The questionnaire is then designed to test seven main aspects (categories). Such categories are chosen based on the previous interviews and available facts related to the importance of the DSF in environmental architecture. These categories are: the complex and its DSF importance in Kuwait history as an icon of the 1960s modern era, the importance of the openings and windows (general and indoor space location significant), view (daylighting), natural ventilation (IAQ), thermal comfort, and sound pollution (acoustics).

The questionnaire is printed on an A3 folded paper to make it easier on the participant. In order to spread the questionnaire the authors were assisted by one employee of building A. The employee took 2 days to distribute the questionnaire to a maximum amount of participants. The authors distribute the rest of questionnaire to building B and C. It took 3 days to be succeeded to reach the majority of each floor of the two buildings. Building $\mathrm{B}$ took 2 days and building $\mathrm{C}$ took one day. The started time to manage in distributing the questionnaire was from 9 a.m. to 12 noon. The author spent 17 days to get the participants' responses and transfer them to Excel spreadsheet. The questionnaire questions are divides into three different types: type "A", "B", and "C". Type "A" is the first type of selected questions, which consists of one question that corresponds to "important, not important, I don't care" answers. Type "B" selected questions consist of six questions that correspond to "excellent, very good, good, fair or poor response. Type " $C$ " selected questions are 13 questions that correspond to "yes, no or I don't' care" answers. These types of questions are reorganized and presented in Tables 2 to 8 in the discussion of results section. 
Table 1: Questionnaire questions about the significance and importance of the DSF in the historical Municipality complex of Kuwait City.

\begin{tabular}{|c|c|}
\hline Question & Question Category \\
\hline 1. The complex was built in 1955. Do you consider it a historical value for the country to rehabilitate it? & Historical \\
\hline 2. Do you prefer removing the complex and building a modern one? & Historical \\
\hline 3. How do you generally evaluate the external green façade of the complex? & General \\
\hline 4. Does your office overlook onto any external window or is it near it? & Indoor Space Location \\
\hline 5. Does your office overlook the external green façade? & Indoor Space Location \\
\hline 6. How do you evaluate sunray's arrival to your office? & Daylighting \\
\hline 7. Do you generally prefer natural lighting through the window of the building? & Daylighting \\
\hline 8. Does lack of windows effect on your performance at work? & Daylighting \\
\hline 9. How do you generally evaluate the importance of existing windows in the building? & General \\
\hline 10. Is your office located in the zone where the internal façade is removed? & Indoor Space Location \\
\hline 11. Are you satisfied with the removal of the internal façade? & Historical \\
\hline 12. Are you for rehabilitating and maintaining the external green façade? & Historical \\
\hline 13. Are you for exchanging the external green façade with a new design? & Historical \\
\hline 14. Do you prefer bringing back the external corridors ( $2 \mathrm{~m}$ after the external green façade) to rehabilitee them? & Historical \\
\hline 15. Are you with planting the external corridors "Cavity" with internal plants to be a breather for all offices? & IAQ \\
\hline 16. How do you evaluate the temperature of the office in winter? & Thermal Comfort \\
\hline 17. How do you evaluate the indoor temperature of the office in the summer? & Thermal Comfort \\
\hline 18. Do you prefer the natural ventilation through the office window with the air conditioning? & IAQ \\
\hline 19. Do you prefer the mechanical to passive cooling? & IAQ \\
\hline 20. How do you evaluate the natural ventilation according to the healthy effect of the external green façade? & IAQ \\
\hline 21. Do you hear any outdoor noise? & Acoustics \\
\hline
\end{tabular}

\section{Case Study}

Kuwait Municipality complex consists of three buildings; A, B, and $\mathrm{C}$ as shown in Fig. 1 and Fig 4. It has a significant impact on Kuwait history as it symbolizes modernity and democracy. In fact, the complex is a sign of the first legitimate governmental buildings after independence. Building A is used to represent the first National Assembly of Kuwait (29th Jan., 1963 - 23rd Feb., 1986). It is currently used as The Town Council. Building B and $\mathrm{C}$ are used as office spaces for municipality employees.

The Municipality complex represented the modernity era of the 1960s [8]. It was built with a double skin façade with operable windows as occupants' option for passive ventilation. The complex was also equipped with two Worthington chillers to meet the indoor thermal comfort. In addition to the function of the façade, its modern and fashionable image added an iconic

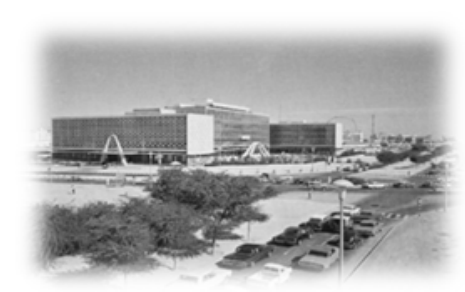

Fig. 4. Kuwait Municipality Building in the 1960s [26].

structure in the city's 1960's modern skyline as shown in Fig. 4 [7], [8].

The complex represented a period where technology was extremely scarce in an era where environmental adaptation is crucial for occupants' comfort. In fact, passive environmental techniques where the only available technique in most buildings of that era. It is therefore a great example to demonstrate the 
impact of such system in the harsh environment of Kuwait; knowing that it is an example that is considered to be a symbol of modernity and democracy. In fact, it is the belief of the authors that this is the moment where such system (DSF) is needed to be rehabilitated and adapted within a sustainable building context.

The double skin façade (DSF) in Kuwait Municipality complex consists of three main parts: the external façade, the cavity, and the internal skin. The external façade is basically a green double glass curtain wall covering all the building facade except the ground floor, which is provided with $60 \mathrm{~cm}$ thick concrete blocks with operable box window DSF type. The external façade has upper operable windows for ventilation. The cavity is $2 \mathrm{~m}$ wide with a $20 \mathrm{~cm}$ gap between the external façade and the cavity overhang. The internal skin depth is $60 \mathrm{~cm}$ [8] that consists of a $20 \mathrm{~cm}$ concrete block, $20 \mathrm{~cm}$ air gab, and $20 \mathrm{~cm}$ concrete block. This DSF can be characterized as a corridor type with a multi $2 \mathrm{~m}$ by $1.75 \mathrm{~m}$ double glassed windows in the internal skin, Fig. 5, 6, 7 and 8 .

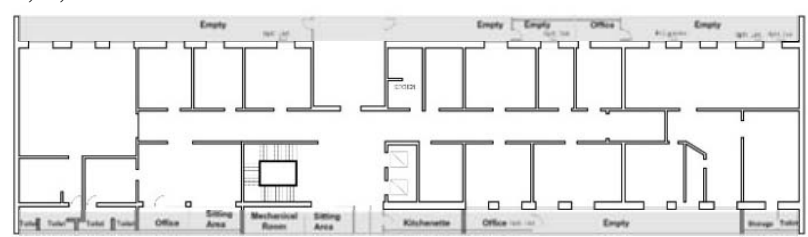

Fig. 5. The 2nd floor Plan of building A; as built drawing provided by the mechanical division of the maintenance department of Kuw ait Municipality [27]

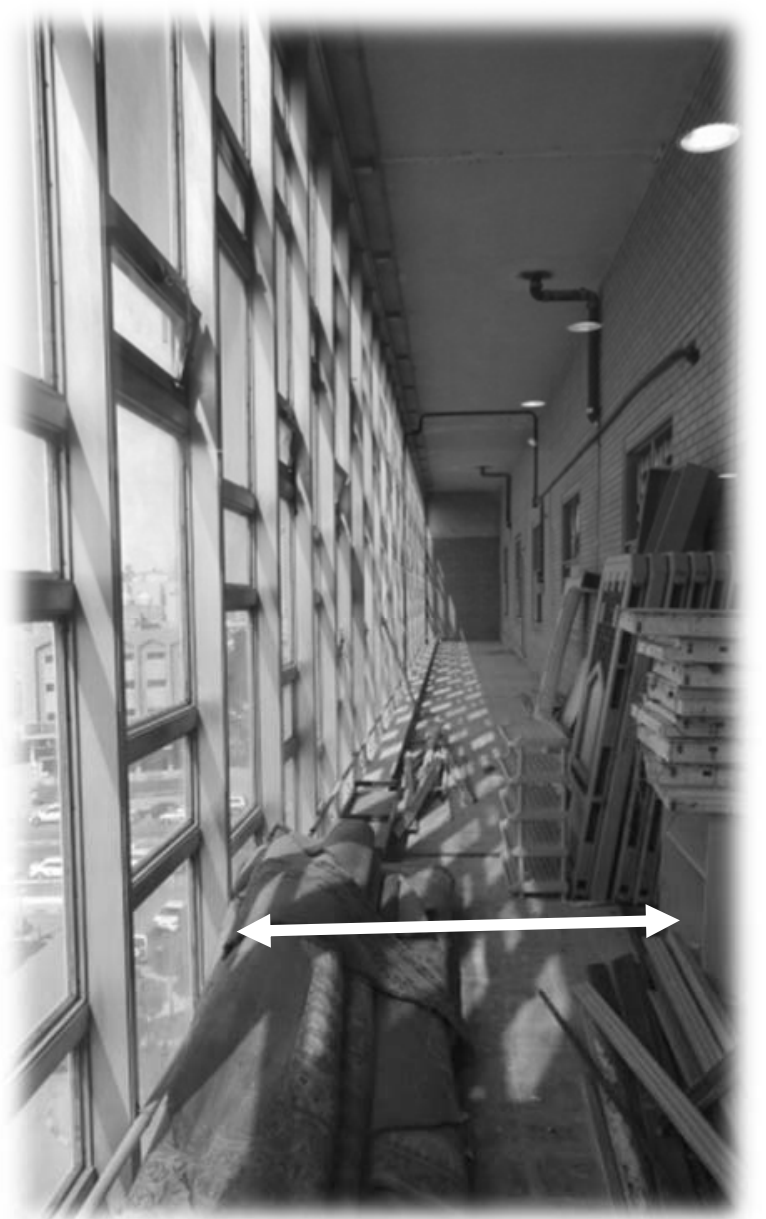

Fig. 6. The current external façade shows the cavity and the internal skin of the last floor of building $B$ [28]
The total foot print area of the complex is around 4,582 $\mathrm{m} 2$ with a total built up area of around 25,201 m2. The complex is served by a central cooling plant that contains 2-550 thermal tons McQuay chillers, 1-750 thermal tons Trane chiller and another 1-250 thermal tons Trane chiller. So the total chiller size of the complex is 2.100 thermal tons. Each floor of the three buildings is served by 2 constant volume AHU's [7].

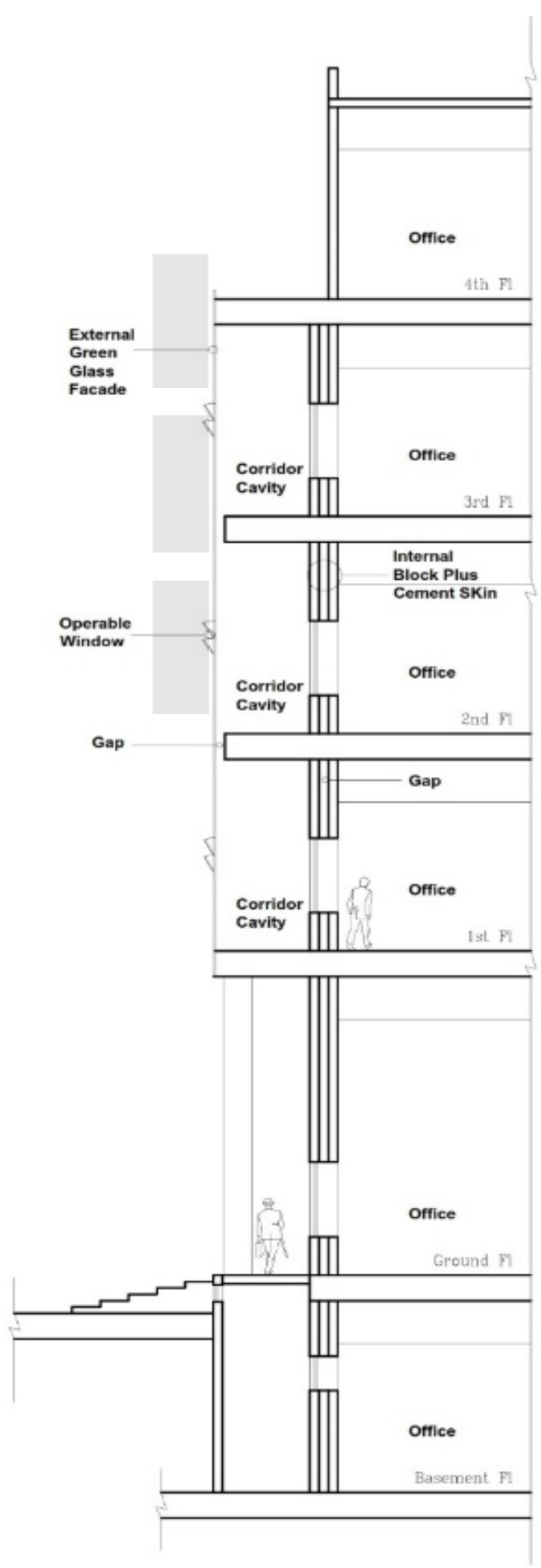

Fig. 7. A typical floor section drawn by the authors [28]. 


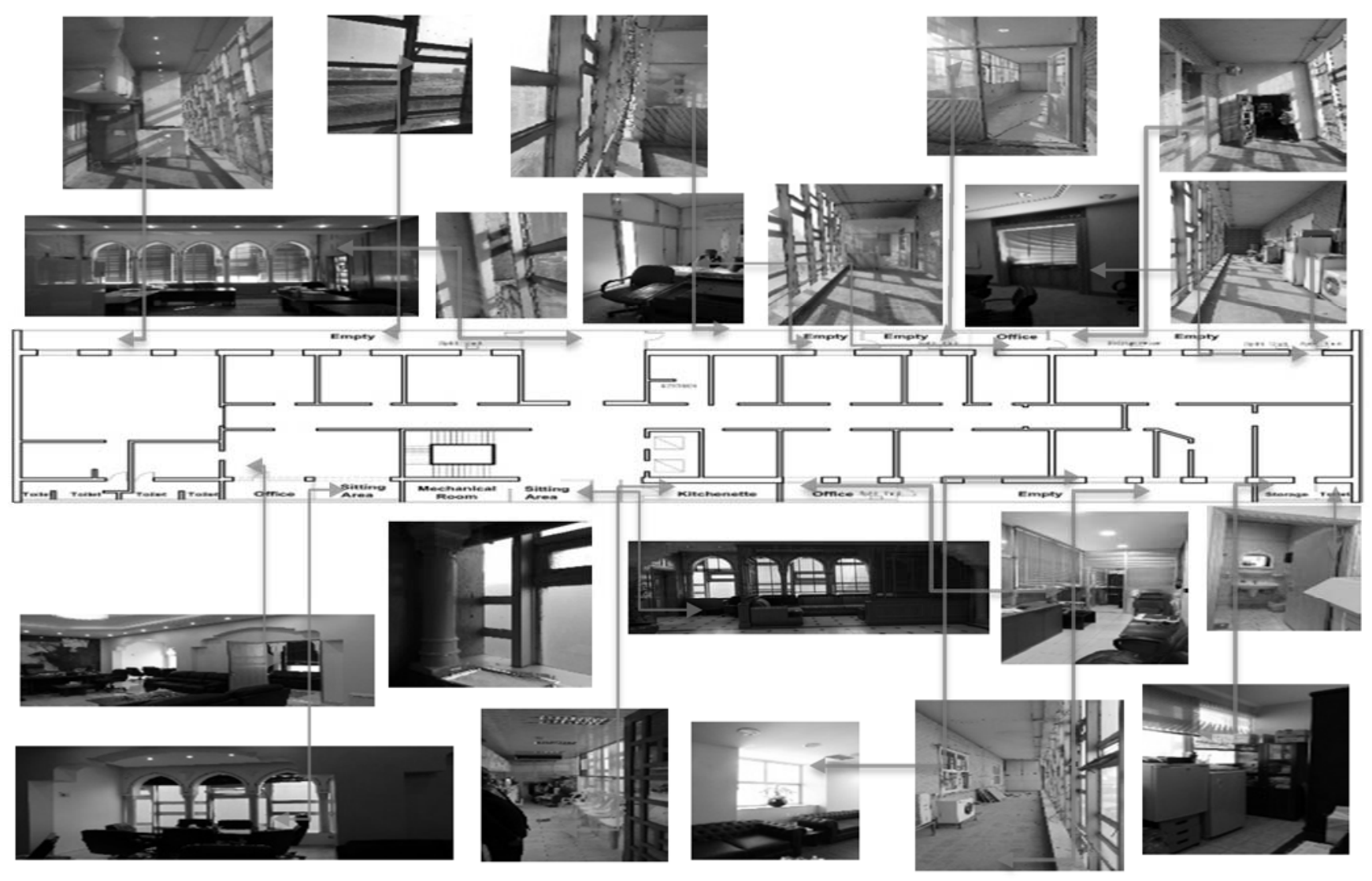

Fig. 8. A typical floor in the second floor (building A), which shows the current situation of the cavity corridors in that floor [28]

Table 2: General category questions

\begin{tabular}{|c|c|c|c|c|c|c|c|}
\hline Type A. Question & & Importan & & Not Important. & I don’t Care & No Answer & Total Answers \\
\hline 9. How do you generally evaluate the importance of existing win & dows in the building? & 294 & & 15 & 10 & 2 & 321 \\
\hline Type B. Question & Excellent & Very Good & Good & Fair & poor & No Answer & Total Answers \\
\hline $\begin{array}{l}\text { 3. How do you generally evaluate the external green façade of } \\
\text { the complex? }\end{array}$ & 46 & 64 & 91 & 53 & 66 & 1 & 321 \\
\hline
\end{tabular}


Al Anzi et al. / Int. J. of Thermal \& Environmental Engineering, 14 (2017) 71-82

Table 3: Indoor Space Location category questions

\begin{tabular}{|c|c|c|c|c|c|}
\hline Type C. Question & Yes & No & I don’t Care & No Answer & Total Answers \\
\hline 4. Is your office beside any external window or is it near it? & 228 & 90 & 2 & 1 & 321 \\
\hline 5. Is your office beside the external green façade? & 179 & 141 & 0 & 1 & 321 \\
\hline 10. Is your office located in the zone where the internal façade is removed? & 107 & 185 & 8 & 21 & 321 \\
\hline
\end{tabular}

Table 4: Historical category questions

\begin{tabular}{|c|c|c|c|c|c|}
\hline Type C. Question & Yes & No & I don’t Care & No Answer & Total Answers \\
\hline $\begin{array}{l}\text { 1. The complex was built in } 1955 \text {. Do you consider it a historical value for the country to } \\
\text { rehabilitate it? }\end{array}$ & 237 & 71 & 8 & 5 & 321 \\
\hline 2. Do you prefer removing the complex and building a modern one? & 95 & 212 & 10 & 4 & 321 \\
\hline 11. Are you satisfied with the removal of the internal façade? & 136 & 104 & 67 & 14 & 321 \\
\hline 12. Are you for rehabilitating and maintaining the external green façade? & 260 & 35 & 22 & 4 & 321 \\
\hline 13. Are you for exchanging the external green façade with a new design? & 164 & 128 & 22 & 7 & 321 \\
\hline $\begin{array}{l}\text { 14. Do you prefer bringing back the external corridors ( } 2 \mathrm{~m} \text { after the external green façade) to } \\
\text { rehabilitee them? }\end{array}$ & 192 & 96 & 26 & 7 & 321 \\
\hline
\end{tabular}

Table 5: Daylighting category questions

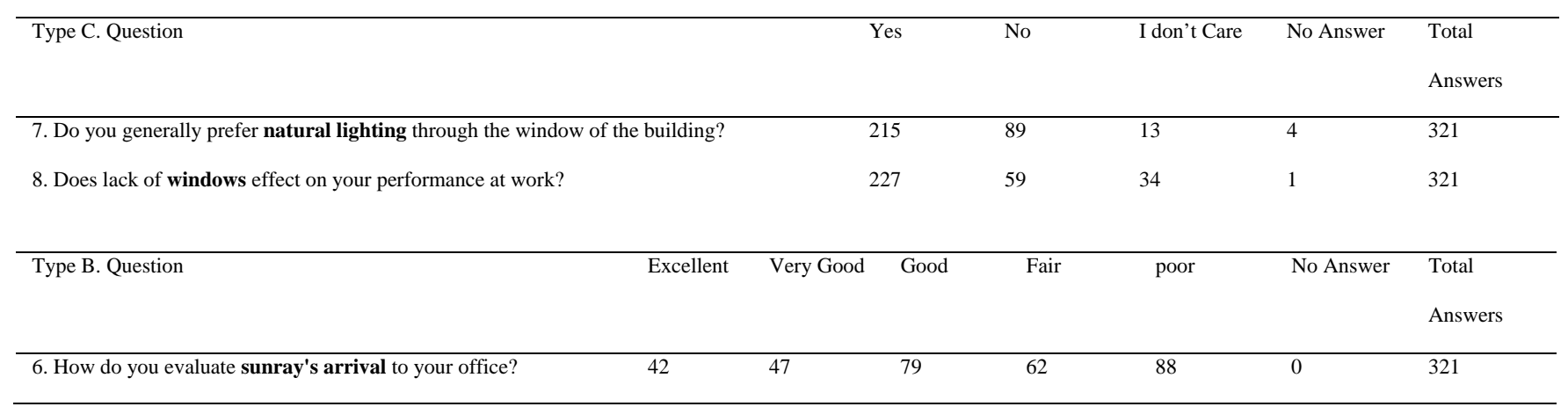

Table 6: Thermal Comfort category questions

\begin{tabular}{|c|c|c|c|c|c|c|c|}
\hline Type B. Question & Excellent & Very Good & Good & Fair & poor & No Answer & $\begin{array}{l}\text { Total } \\
\text { Answers }\end{array}$ \\
\hline 16. How do you evaluate the temperature of the office in winter? & 36 & 89 & 116 & 54 & 23 & 0 & 321 \\
\hline $\begin{array}{l}\text { 17. How do you evaluate the indoor temperature of the office in the } \\
\text { summer? }\end{array}$ & 56 & 89 & 104 & 39 & 28 & 5 & 321 \\
\hline
\end{tabular}


Table 7: IAQ category questions

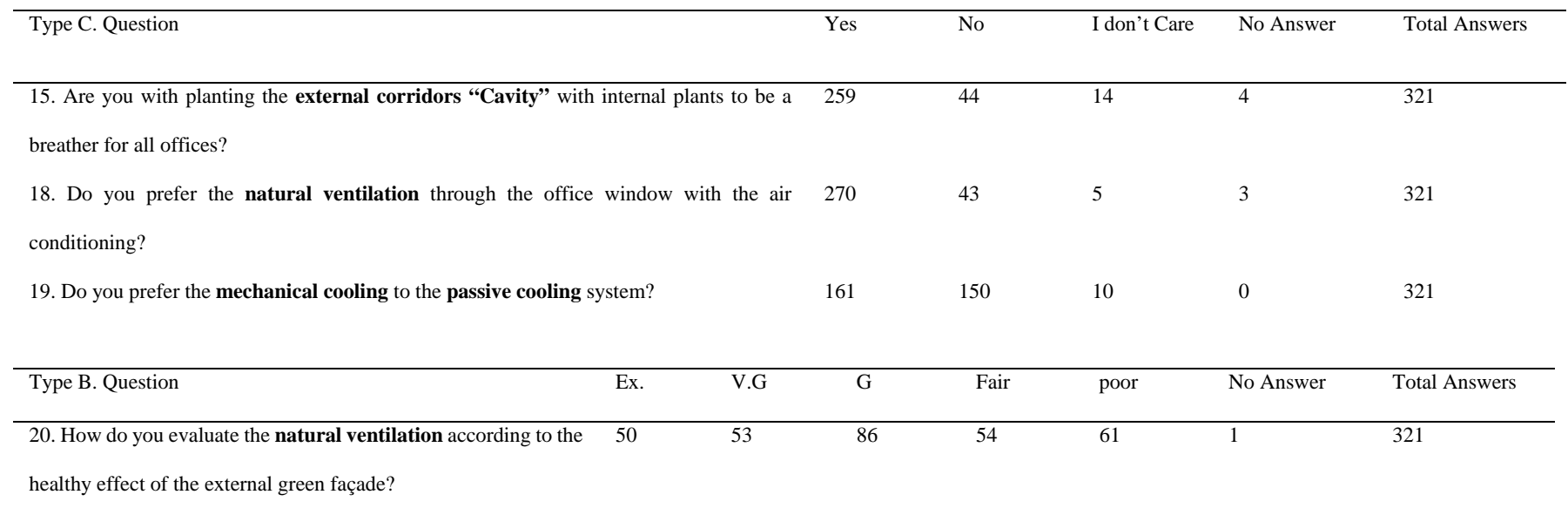

Table 8: Acoustics category questions

\begin{tabular}{|c|c|c|c|c|c|}
\hline Type C. Question & Yes & No & I don’t Care & No Answer & Total Answers \\
\hline 21. Do you hear any outdoor noise? & 101 & 201 & 13 & 6 & 321 \\
\hline
\end{tabular}

\section{Discussion of Results}

Further organization of the questionnaire responses is done to relate the seven different building aspects (categories) to the questions as mentioned in the methodology. Tables 2 to 8 present the organized questions along with the responses of occupants.

The organization of results necessitates the beginning with different question order. Therefore, it is important to start with question 9 (Table 2), since it is the most general one. The response of Q9 indicate that more than $90 \%$ of the occupants give positive answer to the importance of windows in their spaces as shown in Fig. 9. (a). In addition, occupants give a very positive response to the evaluation of the external green façade in Q3. In fact, $28 \%$ give good response, while $34 \%$ give excellent and very good responses. In total $97 \%$ of the occupants have a positive satisfaction to the external green façade as shown in Fig. 9. (b).

Table 3 lists the responses of occupants to the space locations in vicinity to windows access. In particular, questions Q4, Q5 and Q10 are intended to measure the percentage of offices with window views. There are two different windows in the complex, the DSF and the conventional windows. Some of the DSF windows were modified by the removal of the internal skin. This in turn change it into a conventional one. Result of this question category indicate that $71 \%$ of the office spaces have windows. In particular $75 \%$ of spaces with windows are beside DSF ones. It is worth mentioning that all conventional windows where originally DSF, but modified by the removal of the internal skin. In addition, only $47 \%$ of spaces with windows are located in offices where the internal skin is removed. The relevance of this question type shows that most office spaces (53\%) are beside the original DSF, which measures the perception of occupants to the original intention of the DSF as shown in Fig. 10.

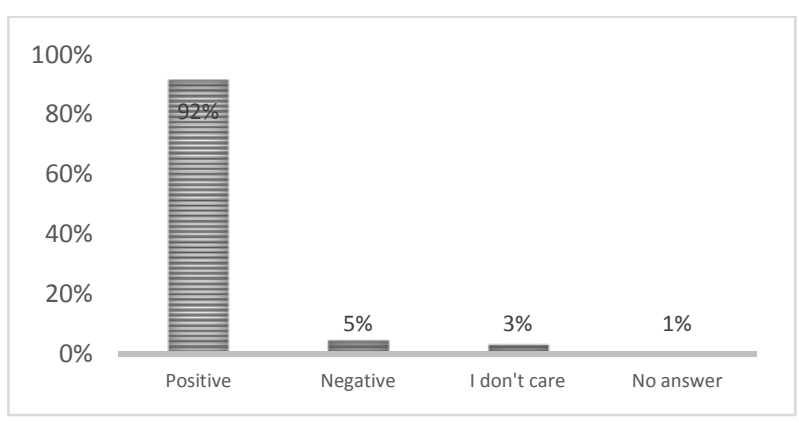

(a)

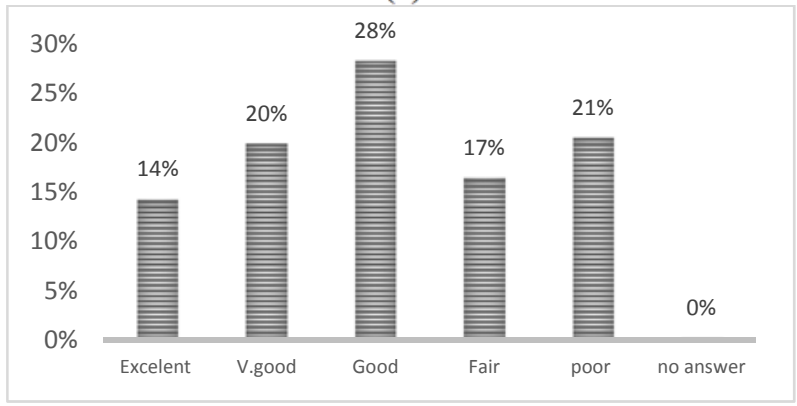

(b)

Fig. 9. Responses to questions 9 and 3. (a) Q9 and (b) Q3

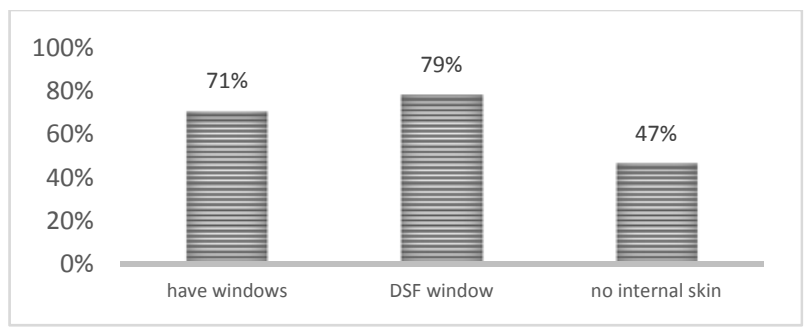

Fig. 10. Responses to Q4, 5 and 10 
The first presented category of question is related to the historical importance of the complex as shown in Table 1 and Table 4. Analysis of responses to this question indicates that around $74 \%$ of the occupants are in favor of preserving the historical building as indicated in Q1. In addition, 66\% of responses answer no to Q2, which indicates the refusal of occupants to the removal of the current complex. Furthermore, $34 \%$ of the occupants even refused the removal of the internal skin as shown in Q11. In response to the complex rehabilitation, $80 \%$ are in favor of rehabilitation the DSF, while $51 \%$ are in favor of new design as indicated by Q12 and Q13 respectively. Finally, Q14 shows a very positive response to the occupants' satisfaction with the DSF. In fact, $60 \%$ of the occupants are in favor of restoring the building to its original DSF design as shown in Fig. 11. (a). Further analysis to this question category is presented by the answers as positive and negative responses to the appreciation of the DSF. In particular, the average positive answers to Q1, 2, 11, 12, 13 show that $59 \%$ of the occupants are in favor of the original DSF as shown in Fig. 11. (b).

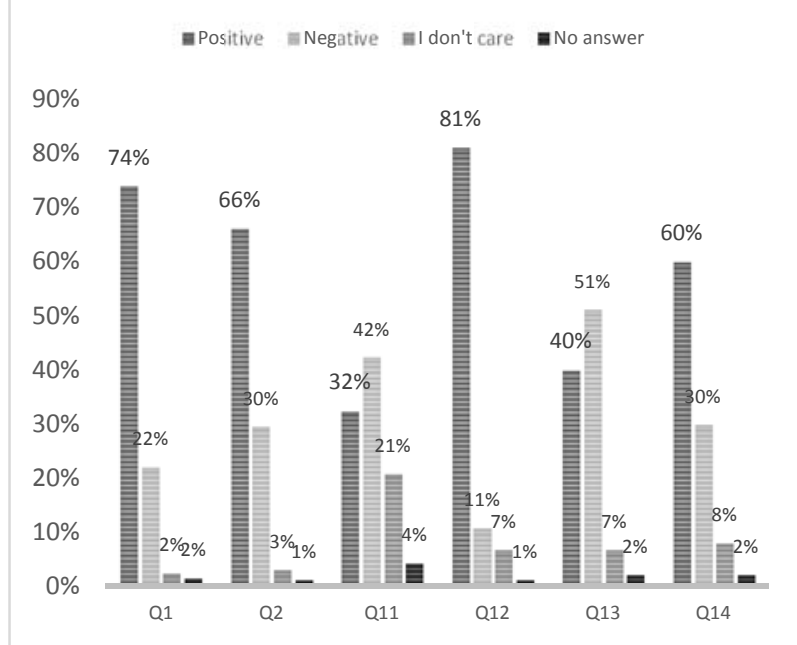

(a)

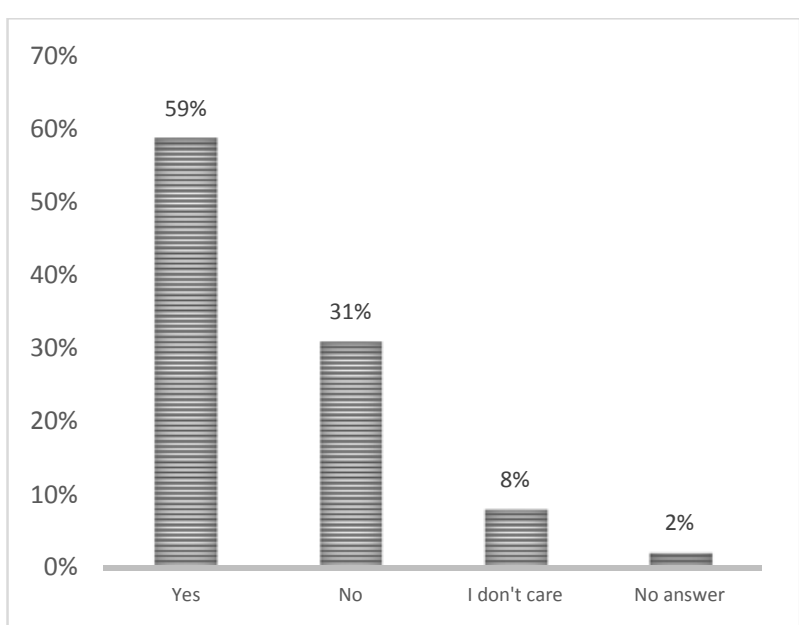

(b)

Fig. 11. Responses to Q1, 2, 11, 12, 13 and 14. (a) Q1, 2, 11, 12, 13 and 14, and (b) the average positive (Yes) responses to Q1, 2, 11, 12, 13 and 14

Daylighting question category (Table 5) is probably the most important one, due to its relation to occupants' performance and wellbeing. The response to the benefits of DSF is very positive in this category. In fact, Q7 shows that $67 \%$ of occupants' prefer natural lighting and $71 \%$ feel that their performance is affected by the existence of windows in their spaces as indicated in Q8 and illustrated in Fig.12(a). An important implicit finding in this category is related to Q6, where most of the negative responses regarding daylighting quality is from occupants of block B. This is due to the fact that their offices are located on the east side. In fact, around $30 \%$ of the occupants of this block have a poor answer responses to the quality of daylighting. This is most probably related to extensive glare experience on the morning hours.

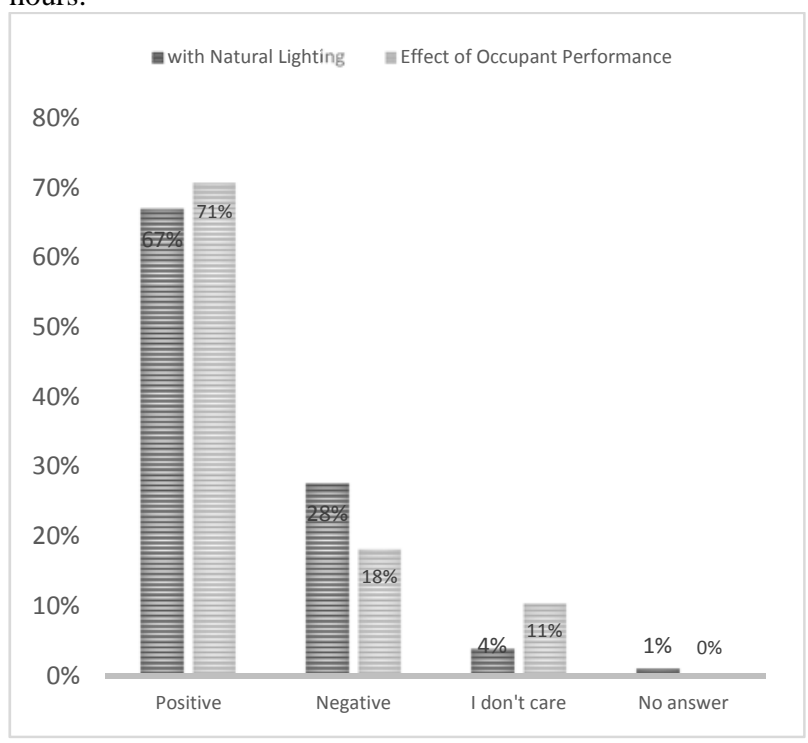

(a)

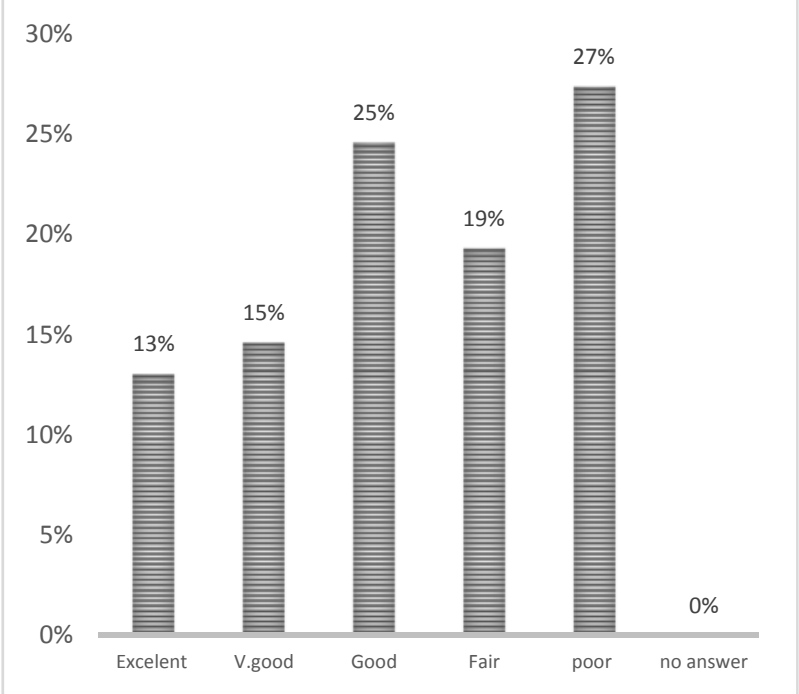

(b)

Fig. 12. Responses of $Q 7$ and 8. (a) $Q 7 \& 8$ and (b) $Q 6$

Table 6 demonstrates the occupants' responses to the spaces thermal comfort. Most occupants have positive response regarding the satisfaction to the indoor air temperature throughout the year. In fact, around $92 \%$ and around $90 \%$ of the occupants responses range between excellent to fair in Q16 (winter indoor temperature) and Q17 (summer indoor temperature) accordingly. These responses are really a great indication to good thermal comfort, since the satisfaction of the thermal environment exceeds $80 \%$ of the occupants. Fig. 13 illustrate the responses to Q16 and Q 17. Further thermal investigation is required to study the thermal behavior of the complex. It is really strange to get positive thermal comfort response in this old and poor thermal envelope. The authors have a great doubt that this positive thermal response is due to very expensive maintenance and operation of the HVAC systems. 


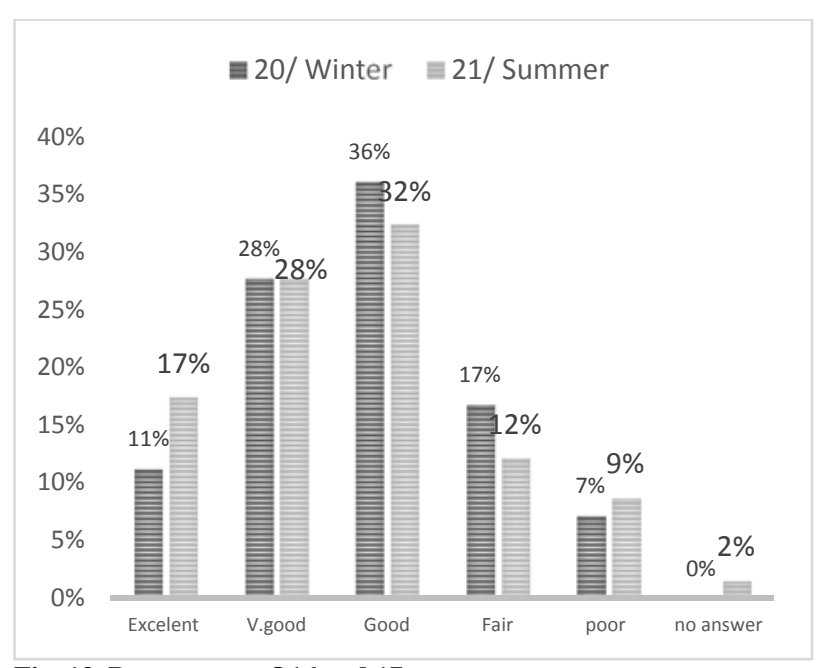

Fig. 13. Responses to Q16 and 17

The IAQ category question (Table 7) will assess in developing decision strategies for the complex's DSF rehabilitation. The IAQ questions are summarized in Q15, Q18, Q19 and Q20, and they are related to the relationship between the DSF and its IAQ benefits. In particular, Q15 relates the utilization of the DSF cavity for internal plants. Such strategy will not only improve the IAQ of the spaces, but will improve the psychological feelings of the occupants. A very positive occupants' response is resulted in Q15, where $80 \%$ desire internal plants in the DSF cavity. Q18 relates the occupants' preference to the mode of ventilation choice, where $84 \%$ prefer mixed mode of natural and HVAC ventilation. Q19 checks the preference of occupant's to passive cooling option as the only mode of thermal comfort. This question is intended to sense the degree of occupants' appreciation to IAQ. The response to this question is that $50 \%$ prefer mechanical cooling, while $47 \%$ prefer passive cooling. This is honestly a good indication of IAQ appreciation, since around half of the occupants don't mind working in a passively cooling space conditions as shown in Fig. 14.

The last question in this category is Q20, which is the occupants' general evaluation of the ventilation health effect of the existing DSF. The response to this question indicate that $76 \%$ (between excellent to fair) are satisfied with their healthy condition of the complex's indoor spaces. The response to this question indicates a healthy indoor conditions. Again, the authors insist that further evaluation of the thermal building behavior is necessary to justify these extreme positive occupants' responses. In fact, interviews with maintenance engineers revealed many frequent and expensive maintenance bill to the chiller and air handling units. This is most probably due to high envelope infiltration rates that causes occupants satisfaction on the expense of HVAC optimum operation and maintenance.

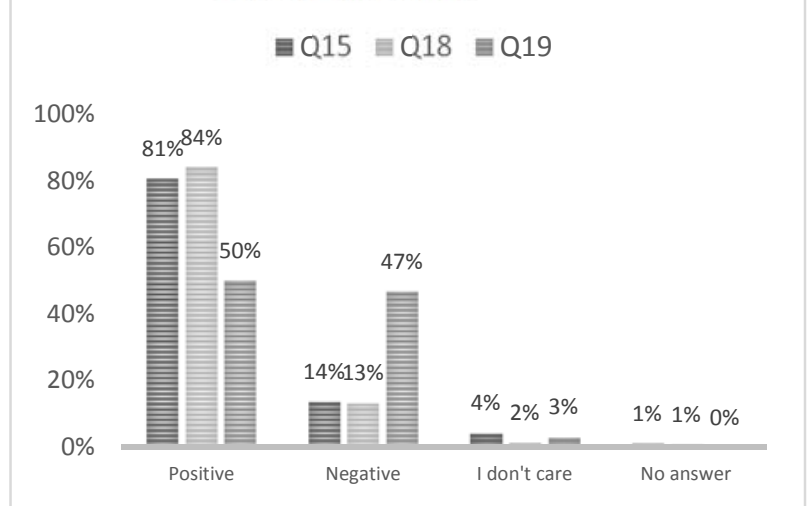

Fig. 14. Responses to Q15, 18 and 19
The final question category (Table 8) is about acoustic's performance of the spaces. Most occupants have DSF windows as shown in Q5 and Fig. 10. According to Q21, most occupants are satisfied with acoustical performance of the DSF, since 63\% of the responses are positive, while $31 \%$ are not satisfied. The authors are not sure why $31 \%$ of the occupants are not satisfied with the acoustical environment as shown in Fig. 15. Due to the fact that this is the only question given in this category, it is recommended to do further investigation on the acoustical performance.

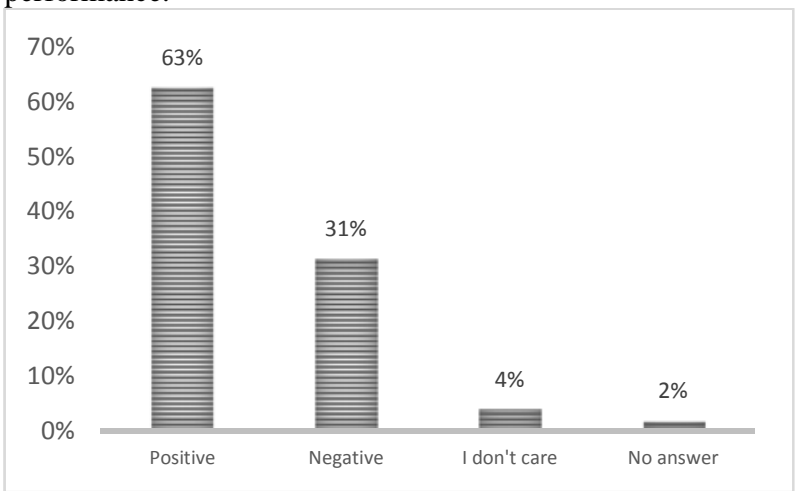

Fig. 15. Responses acoustical performance of Q21

\section{Conclusions and Recommendations}

The findings of this paper assist to put our hands on the malfunction, occupants' misuse and improper maintenance of the DSF of the municipality complex of Kuwait. The complex must be rehabilitated to meet its design functions and intentions in a sustainable manner. In particular, it is necessary that the cavity corridor has to be utilized without losing its main design intention. Many positive responses are reported in this study on the satisfaction of occupants on the daylighting and IAQ of the DSF. But even though, IAQ response by occupants is appreciated and highly positive, they raise concerns regarding the poor envelope condition that cause's definite expensive energy use operation. Other positive occupants' responses that are worth mentioning are the use of internal plants in the cavity, which would improve the indoor environmental quality and reduce glare and improve visual performance. The authors recommend the use of DSF as a strategy to meet occupants' thermal comfort, proper IAQ and energy savings for hot and arid climate. It is also recommended by the authors to use internal plants and shading devices in the DSF cavity corridors to improve indoor environmental quality and to control glare, especially on the east and west side spaces. The authors will use this case study as a base case for future research on the function of the DSF to reach the optimum environmental DSF features for the climatic context of the gulf region. Such study will be carried out using extensive building thermal analysis and energy simulations. 


\section{Nomenclature}

$\begin{array}{ll}\text { AHU } & \text { Air Handling Unit } \\ \text { DSF } & \text { Double Skin Façade } \\ \text { Fig. } & \text { Figure } \\ \text { IAQ } & \text { Indoor Air Quality } \\ \text { Q\# } & \text { Question number }\end{array}$

\section{Acknowledgments}

The authors would like to thank Kuwait Municipality deputy minister Engineer Ahmad Al-Manfouhi and the head of the construction department Engineer Aysha Al-othman for their appreciation and generous help in this study. The authors would also like to thank Engineers Ibrahim Magdi, Mohammad AlGalaf, Ghada Al-Mojalhim and Tarek Wasfi for their great help in providing the necessary information, drawings and data.

\section{References}

[1] Aasem, E. O. (2005, August 31). Suitability of Dual Skin Glass in Hot and Arid climates. Kuwait Institute for scientific Research, Department of Buildings and Energy Technologies. Kuwait: Kuwait Institute for scientific Research.

[2] Aksamija, A. (2013). Sustainable Facades (First ed.). (A. Aksamija, \& P. Will, Eds.) Canada: Wiley \& Sons, John. Retrieved from wiley.com/architecture.

[3] Aksamijia, A. (2009). Context Based Design of Double Skin Facades. Research Journal, 01.01, 54-69.

[4] Causevic, A.; Rustempasic, N.; Zecevic, M. (n.d.). Facade Retention in Case of historical Centre of Sarajevo. University of Sarajevo, Faculty of Architecture. Sarajevo: University of Sarajevo.

[5] Dalangin, M. D. (2013). A Study on the use of Double Skin Facade Systems in the Philippines Based on its properties, Nature and General Use. Philippines: academia.edu. Retrieved April 2, 2013, from academia.edu.

[6] Dooley, K. (2002). Simulation research methods. pp. 829-848. Retrieved from http://www.eas.asu.edu/ kdooley.

[7] Eng. Magdi, I. (2014, November). Engineer in the mechanical division of the constriction department of Kuwait Municipality. (L. Aldihani, Interviewer).

[8] Eng. Wasfi, T. (2014, November 21, 29). Engineer in the maintenance division of the construction department of Kuwait Municipality. (L. Aldiahani, Interviewer) Kuwait.

[9] Eng.Emadi, A. (2014, November 2). The Double Skin Facade of Kuwait Municipality. (L. Al-Dihani, Interviewer) Kuwait.

[10] Gratia, E. \&. (2007). Greenhouse effect in double-skin facade. Energy and buildings, 39(2), pp. 199-211.

[11] Grimmer with Hensley; Petrella, L.; Tepper, A.; (2011). The Secretary of the Interior's Standards for Rehabilitation \& Illustrated Guidelines on Sustainability for Rehabilitation Historic Buildings.
National Park Service; Technical Preservation Services, U.S. Department of the Interior. Washington, D.C.: U.S. Department of the Interior.

[12] Groat, L. \&. (2013). Architectural research methods (Second ed.). United State of America, Canada: John Wiley \& Sons, Inc., Hoboken, New Jersey. Retrieved from wiley.com/architecture.

[13] Hamza, N. (2008). Double versus single skin facades in hot arid areas. 40(3), pp. 240-248.

[14] Hamza, N. A. (2004). The Performance of Double Skin Facade in Office Building Refurbishment in Hot Arid Areas. University of Newcastle upon Tyne, School of Architecture. Newcastle: University of Newcastle upon Tyne.

[15] Hashemi, N. F. (2010). Thermal behaviour of a ventilated double skin facade in hot arid climate. 42(10), pp. 1823-1832.

[16] Heimrath et al. (2005, 12 30). Best Practice for Double Skin Façades. Institute of Thermal Engineering, Graz University of Technology (WP1 Leader). Sweden: BESTFACADE and Intelligent Energy Europe. Retrieved 12 30, 2005.

[17] Høseggen, R. W. (2008). Building simulation as an assisting tool in decision making: Case study: With or without a double-skin façade. 40(5), pp. 821-827.

[18] Louncour, X., Wouters, P., Flamant, G., \& Blasco, M. (2003). Impact of Double Ventilated Facade in Buildings. Belgian Research Institute (BBRI), Building Physics and indoor Climate. Belgium: Belgian Building Research Institute (BBRI).

[19] Poirazis, H. (2006). Double skin facades. Lund Institute of Technology (LTH), Department of Architecture and Build Environment. Sweden: Lund University, Lund Institute of Technology. Retrieved from www.ebd.lth.se

[20] Sharma, R., \& Purohit, D. (2014, August6). Energy efficient facades for Hot and Dry climate in India. IJISET - International Journal of Innovative Science, Engineering \& Technology, 1 (6), 536-542. Retrieved from www.ijiset.com

[21] Weeks, K. D., \& Grimmer, A. E. (1995). The Secretary of the Interior's Standards for the Treatment of Historical Properties. National Park Service; Cultural Resource Stewardship and Partnerships; Heritage Preservation Services, U.S. Department of the Interior. Washington, D.C.: Library of Congress Cataloging-in-Publishing Data.

[22] Ziger, S., Snead, J., Bothner, D., \& Mccormick, H. (1014). zigersnead.com. (Ziger/Snead Architects) Retrieved from Ziger/Snead Architects: http://www.zigersnead.com/office

[23] Google Earth. (2014), [Online Image], Kuwait Municipality Buildings, Kuwait City. Retrieved December 14, 2014 from Google Earth.

[24] Sustainability [diagram]. (n.d.) Retrieved December 12, 2014, from openbuildings.com

[25] Loncour, X., Deneyer, A., Blasco, M., Flamant, G., \& Wouters, P. (2003). Impact of Double Ventilated 
Façade in Buildings, [Printing], a report (p.3). Building Physics and indoor Climate: Belgian Building Research Institute (BBRI).

[26] Online Image. (1960s). The Municipality \& the National Assembly Building. [Photograph], Kuwait Archive. Retrieved December 14, 2014 from Delcampe: www.delcampe.net
[27] Mechanical Department. (2010s). [Drawing], as an Autocad file. Construction Department of Kuwait Municipality.

[28] Al-Dihani, L. (2014). The Rehabilitation of Double Skin Façade of Kuwait Municipality. [Photograph], by the author. College of Architecture. Kuwait University. 